$$
\begin{gathered}
\text { 경주 도심 고분에 대한 지역주민과 관광객의 } \\
\text { 가치체계 비교연구 } \\
\text { - 수단-목적 사슬 이론을 중심으로 - } \\
\text { 석미정 }{ }^{*} \cdot \text { 박종구 }^{* *} \cdot \text { 강태호** }^{* *}
\end{gathered}
$$

"동국대학교 대학원 조경학과 박사수료 · "동국대학교 경주캠퍼스 호텔· 관광경영학과 교수 ·

"동국대학교 경주캠퍼스 조경학과 교수

\title{
A Comparative Study on Resident and Tourist Value Systems of the Ancient Tombs in Gyeong-ju City Center - A Focus on Means-End Chain -
}

\author{
Seok, Mi-Jeong ${ }^{*} \cdot$ Park, Joung-Koo* ${ }^{* *}$ Kang, Tai-Ho ${ }^{* * *}$ \\ "Ph.D, Dept. of Landscape Architecture, Graduate School, Dongguk University Gyeongju Campus \\ ** Professor, Dept. of Hotel \& Tourism Management, Dongguk University Gyeongju Campus \\ ${ }^{* * * *}$ Professor, Dept. of Landscape Architecture, Dongguk University Gyeongju Campus
}

\begin{abstract}
This study aims to conduct a depth analysis of motivation and value of local residents and tourists based on means-end chain theory. The sampling of the study was conducted on local residents living near downtown area of Gyeong-ju City, and tourists through soft laddering and hard laddering methods. A mutual correlation model in relation with Hierarchical Value Map (HVM) for each group by conducting the analysis of factor loading (attributes, consequences, value) and cognitive structure (the correlations among attributes, consequences and value) was proposed and the comparisons of HVM for each group was also conducted. The structured questionnaires using Association Pattern Technique (APT) of hard laddering were utilized to analyze the means and end of value chain structures in terms of the attributes, consequences, value of Gyeong-ju Ancient Tombs. The findings propose that local residents are visiting Ancient Tombs Gyeong-ju City Center for 'Rest and take a walk' as the means, which results in 'Relieving stress' and eventually leads to the 'Improvement of historic and cultural cultivation' as the end. On the other hand, tourists also 'Rest and take a walk' as the mean, which also leads to 'Relieving stress'. However, unlike local residents, it eventually leads to 'Self-reflection and healing' as the end. It is expected that the findings of this study not only recommend us to consider preserving and managing cultural heritages and value of ancient tombs in developing "Ancient Tomb Park in Gyoneg-ju City Center" but also provides baseline data for the establishment of reasonable plans of utilizing tombs, historical and cultural heritages.
\end{abstract}

Key Words: Attributes, Consequences, Value, Association Pattern Technique (APT), Hierarchical Value Map (HVM)

Corresponding author: Tai-Ho Kang, Professor, Dept. of Landscape Architecture, Dongguk University Gyeongju Campus, Gyeongju 38066, Korea, Tel.: +82-54-770-2232, E-mail: kth@dongguk.ac.kr 


\section{국문초록}

본 연구는 '수단-목적 사슬(Means-End Chain: MEC) 이론'을 토대로 경주 도심 고분 인근에 거주하는 지역주민과 관광객에 대한 경주 도심 고분의 방문에 관련한 심층적인 동기 및 가치를 분석하고자 하였으며, 이를 위해 소프트 래더링 (soft laddering)과 하드 래더링(hard laddering) 방법론을 적용하였다. 이를 통하여 경주 도심 방문에 관련된 항목요인(속성, 혜택, 가치)과 인지구조(속성, 혜택, 가치의 연결 관계)를 파악하여 '가치단계도(Hierarchical Value Map)'의 상호 연관 관계모형을 구축함으로써 지역주민과 관광객의 가치체계를 비교하였다. 본 설문조사는 하드 래더링의 연계방식기법 (Association Pattern Technique: APT)의 구조화된 설문지를 활용하여 지역주민과 관광객의 속성, 혜택, 가치에 기반한 수단 (mean)-목적(end) 가치사슬 구조를 분석하였다. 연구결과, 경주 도심 고분을 방문하는 지역주민은 ‘휴식(휴양) 및 산책’을 수단으로 고려하고 있었으며, 이를 통해 결과적으로 그들은 '스트레스 해소'를 경험함과 최종적 목적 상태로 '역사· 문화 보호 의식 배양'에 가치를 두고 있는 것으로 나타났다. 관광객 또한 '휴식(휴양) 및 산책'을 수단으로 고려하고 있었으며, 이를 통해 결과적으로 그들은 ‘스트레스 해소'를 경험함과 최종적 목적 상태로 '자기성찰 및 치유'에 가치를 두고 있는 것으로 나타났다. 이러한 결과를 중심으로 향후 “경주 도심 고분공원” 조성에 있어 우리는 고분의 문화유산 가치 보존 및 관리계획과 더불어 고분 지역주민과 관광객의 행동에 영향을 미치는 방문 가치에 관한 연구를 통해 보다 합리적인 고분 역사·문화 활용계획 방안 수립에 기초적인 자료로 활용이 가능할 것으로 기대된다.

주제어: 속성, 혜택, 가치, 연계방식기법, 가치단계도

\section{I. 서론}

오랜 기간을 통해 형성되어 우리에게 전해 내려오는 문화유 산은 역사적 의미가 중대하고, 다양한 문화적 가치를 지니고 있 다. 문화유산은 과거, 현재와 미래세대를 이어주는 인류 문화의 매개체로써 국가 정체성 형성 및 사회 통합에 기여한다. 또한, 국민들의 문화 향유에도 핵심적인 역할을 한다. 1990년대 이후 국민의 경제 수준 향상에 따라 개인의 삶의 질에 대한 인식 증 가와 더불어 시민사회의 성장, 여가문화의 활성화 등으로 사 회 - 문화적 환경이 변화됨에 따라 국민들은 문화유산에 대한 관심과 보전 인식이 향상되었다. 이에 국가 및 지역 단체는 문 화유산 관련 제도적 정비와 활용 프로그램 운영 등이 시행되었 고, 민간단체는 지속적이고 전문적인 문화유산 보호 및 홍보를 통하여 일반인들에게 문화유산의 주체적인 인식을 고취시켜 자발적인 참여와 활동을 이끌어 내고 있다. 이러한 문화유산에 대한 국가적, 국민적 개입은 진정한 문화유산의 가치를 파악하 고, 이를 활용하여 공공적인 문화의 효용을 높이며, 다양한 경 제적 활동이 이루어질 때 그 정당성을 인정받을 수 있다. 또한, 개입의 진정한 효과를 발휘하기 위해서는 문화유산이 가진 다 양한 가치를 규명하여 공익에 기여할 수 있는 활용 분야를 최대 한 찾아내어 이를 통해 표현되는 문화적 의미가 일상생활에 영 향을 미치면서 삶을 풍요롭게 만들 수 있어야 한다(Lee, 2017).

최근 세계적으로 문화유산에 대한 관심이 높아지면서 개념 이 점차 확대되고, 문화유산이 지니는 가치와 잠재력이 다양하 게 제시되고 있다. 과거로부터 전해온 우리의 문화유산 가치를 이해하고, 보존, 활용하여 후대에게 전해주는 일련의 행위들에
있어 문화유산이 지닌 '가치'는 문화유산의 다양한 사회적 행 위를 하고 있는 이유이며 목적이기도 하다(Lee, 2018). 특히 문화유산 보존의 이유이자 보존 방법을 논하는 핵심적 요소가 문화유산의 가치라는 점이 인정되면서 국내· 외에서는 문화유 산이 지니고 있는 다양한 가치들의 정의와 평가에 대한 연구가 다면적으로 깊이 있게 진행되고 있다. 이러한 연구 결과를 통 하여 문화유산을 관리하는 국가기관과 공공단체에서는 가치에 바탕을 둔 보존과 관리 및 활용 계획들이 적극적으로 도입되고 있다. 이에 우리는 문화유산 자체에 절대적인 가치를 부여하며, 과거 지향적인 보존과 복원에 치중하는 상태에서 벗어나 문화 유산의 상태를 유지 보존하되, 현재 우리에게 부여되는 문화유 산의 가치를 파악하여 이를 현실 참여적인 교육, 여가, 관광 등 의 활용방안을 모색함으로써 해당 문화유산 지역의 정체성 형성 및 다양한 문화적 공헌으로 이어져 차별적인 지역 경제 활성화 및 새로운 부가 가치가 창출될 것이다. 이러한 방안들은 우리의 정서와 삶의 질을 향상시킬 것이며, 이때 진정한 문화 유산의 가치 창조가 이루어질 수 있다. 이와 같은 측면에서 경주 도심지에 집중적으로 분포된 고분은 인류 역사의 산물로써 귀 중한 문화유산이며, 특히 이곳은 오래 전 고분 일대를 삶의 터 전으로 만들어 살아가는 지역주민과 함께 어우러진 특유의 역 사- 문화적 공간으로 단순히 고분만이 존재하는 것이 아니라, 지역주민의 삶이 이어지는 곳이기에 더욱 세심한 고분의 보존 및 관리와 더불어 효율적이고 합리적인 활용방안이 정책적으로 실현되어야 한다.

이를 위해서는 지역주민과 관광객의 초점에 맞추어 그들이 인식하는 경주 도심 고분 방문의 행동 원인 또는 동기에 대한 
이해를 위해 고분 방문에 관련된 주요 방문 선택 속성, 그로 인 한 결과적인 혜택과 최종적 가치의 중요 요인과 그들의 행동을 지배하는 주된 가치체계가 무엇이가를 우선적으로 파악해야 할 것이며, 이를 통하여 전략적인 고분의 자원 관리 및 활용 계획 을 제시하고자 한다.

이에 본 연구는 수단-목적 사슬(MEC) 이론을 기반으로 래더 링(laddering) 방법론을 적용하여 경주 도심 고분을 방문하는 지 역주민과 관광객들이 최종적으로 얻게 되는 궁극적 가치를 분 석하고, 이러한 가치를 제공하는 구체적인 혜택과 이에 기반이 되는 중요한 고분의 속성을 규명하였다. 이를 통해 최종적으로 경주 도심 고분에 대한 지역주민과 관광객의 '속성-혜택-가치' 간의 계층적 인지구조의 가치사슬인 가치단계도(HVM)를 통 해 비교·분석하고자 한다.

\section{II. 이론적 고찰 및 관련 연구 동향}

\section{1. 경주 도심 고분의 개념 및 범위}

\section{1) 사적과 고분의 개념}

경주의 도심에 서로 인접하여 분포되어 있는 고분은 2011년 7월 문화재청이 역사성과 특성을 고려하여 신라시대의 고분군 을 통합하고 사적 512호로 재지정하였다. 고분은 문화재 평가 요소인 역사 - 학술 - 예술 - 경관적 기준에 따라 중요도가 결정 되며, 문화재보호법상 기념물군에 속하며 중요도에 따라 국가 지정문화재(사적), 시도지정문화재(시도지정기념물), 문화재자 료 등으로 지정되어 관리되고 있다. 우선, '사적'의 사전적 의미 는 역사상으로 남아있는 중대한 사건이나 여러 가지 시설 등의 특별한 역사- 학술적 가치를 지닌 자취를 말한다. 문화재 보 호법상 사적은 역사적 사건과 관계가 있는 장소, 유적지, 구역, 고 건축물, 유구 및 특별한 가치를 가진 물건, 유물 등으로 문 화재 가운데 역사- 학술 - 경관상 가치가 큰 유적지로 국가가 법적으로 특별히 지정한 것이다(Cultural Heritage Administra tion, 2007). 사적은 역사적 장소, 고 건축물 및 유구 등 공간의 면적 단위와 밀접한 관련을 맺는 개념으로(Cultural Heritage Administration, 2009) 이는 과거 한 시기의 역사적 활동과 사 고만을 간직한 것이 아니라 오랜 시간을 통해 축척되어져 우리 에게 전해진 역사적 산물이다.

'고분'의 사전적 의미는 선사와 고대의 무덤 중 역사적 또는 고고학적 자료와 학술적 가치가 될 수 있는 성토한 분묘로 과 거의 사람의 시신을 매장한 시설물로써 시신 부패로부터 위생 적 처리로부터 발생하였다. 그러나 학계에서의 전문용어로 고 분은 개념적으로 엄격히 한정하여 사용하게 되는데, 여러 가 지 기준에서 그 범주를 정의한다(Cultural Heritage Administra tion, 2009). 우선 매장의 무덤 역사는 후기 구석기시대 당시 지 면을 파서 구덩이를 만들고, 시신을 넣은 후 흙을 덮었으며, 인
간의 지능이 발달함에 따라서 무덤은 기념물화 되어 시설이 확대되고 견고하게 만들어졌다. 시대적으로는 삼국시대의 무 덤에 대하여 고분이라 하며, 정치사적으로는 지역에 수장권 확 립으로 지배집단을 위해 일정 규모 이상의 매장시설과 무덤의 외관이 갖춰져 지배 권력을 상징하는 장신구와 무기 등이 풍부 하게 매납되었다. 대규모의 매장시설과 화려하고 풍부한 부장 유물을 가지는 최고지배자 무덤의 출현을 전제로 하며, 일정한 수준 차이를 보이는 상하위의 무덤을 일괄하여 고분으로 개념 을 규정한다(Cultural Heritage Administration, 2009). 또한, 역 사적으로 고분은 학술적 가치와 다양한 정보를 지니고 있으며, 현 상태를 유지시키는 행위 외에 이를 계승하고 발전해 나가야 한다. 이를 위해 사적과 사적지를 구성하는 모든 요소들이 하 나의 문화적 단위로 일체화되어 주변과의 조화로운 관계가 유 지되어야 한다.

\section{2) 경주 도심 고분의 범위 및 현황}

경주 도심 고분을 동으로 구분하면, 현재 경주 노동동 4 기, 노서동 13 기, 황오동 13 기, 황남동 45 기, 인왕동 10 기, 총 85 기가 약 $85 \mathrm{ha}$ 에 분포되어 있다. 그 중 고분 미발굴 상태의 61 기 중 봉분이 보존된 고분은 28 기와 봉분이 소멸된 고분은 33 기, 또 한 발굴된 24 기 중 봉분이 복원된 고분은 4 기와 봉분이 미복원 된 고분은 20기로 확인된다(Figure 1 참조).

이러한 고분을 활용한 경주시의 역사문화도시조성사업은 문 화유산 정비 사업에 가장 중심이 되어 추진 중에 있으며, 현재 경주시는 단계적인 고분의 발굴조사를 통해 신라왕경 관련 유 적지에 대한 실용적인 복원 안 도출 및 고도의 도시구조와 생 활상 회복을 위한 문화유적 복원계획이 진행 중에 있다. 그 중

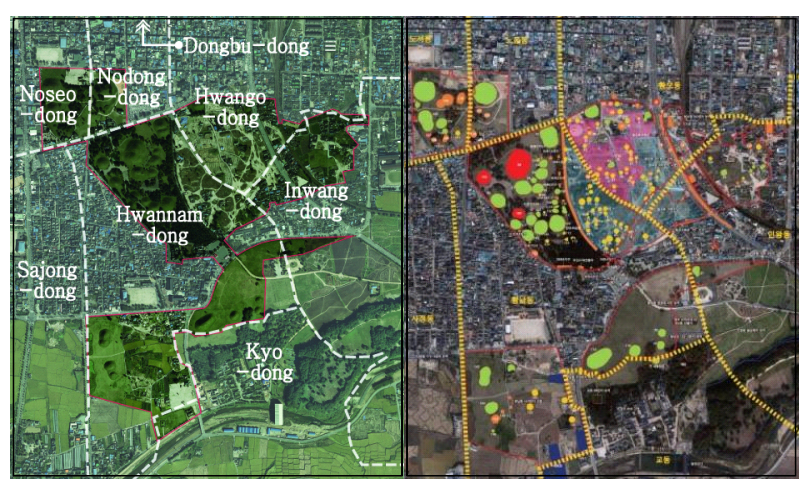

Figure 1. A research site and distribution status of the ancient tombs in Gyeong-ju city center

$\begin{array}{lll}\text { Legend: 1. Dongbu-dong } \quad \text { 2. Nodong-dong } & \text { 3. Noseo-dong }\end{array}$ 4. Hwannam-dong 5. Hwango-dong 6. Inwang-dong $\begin{array}{ll}\text { 7. Kyo-dong } & \text { 8. Sajong-dong }\end{array}$

- The preservation of ancient tombs(excavate)

The disappearance of ancient tombs(non-excavated)

- The restoration of ancient tombs(post-excavation)

- Ancient tombs not restored (post-excavation) 
'경주 도심 고분공원' 조성 사업계획은 2007년부터 2025년까 지 국비, 지방비의 투자로 체계적인 학술조사 및 정비·복원 사업을 통해 도로, 광장, 휴양- 편익시설을 갖추고, 역사· 문화 유적의 철저한 보존뿐만 아니라, 관광객과 주민들에게 유익한 공간을 제공하고, 역사 유적지와 연계한 관광 및 녹지 네트워크 구축으로 경주의 지역 활성화를 위한 중요 사업으로 인식되고 있다. 이러한 사업계획의 기초자료 확보를 위해 2007년부터 추 진된 '경주 쪽샘지구 신라고분유적(국립문화재연구소)' 발굴조 사는 봉토분 확인, 분포 조사를 시작으로 발굴 대상지를 $\mathrm{A}$ 지구 에서 $\mathrm{N}$ 지구로 구분하여 고분 조사 및 발굴이 진행 중에 있다.

\section{2. 수단-목적 사슬(MEC)이론}

$\mathrm{MEC}$ 이론은 어떻게 상품 또는 서비스가 수단(means)으로써 개인이 인지하는 일상적인 관계에서 어떠한 목적(end)으로 관 련되어 있는지를 설명한다. Gutman(1982)은 “수단'을 상품 혹 은 사람들이 관계하는 활동을 속성으로, 이를 통해 얻게 되는 결과적인 혜택은 속성에 의해 생산된 산물이며, 최종적인 '목 적'은 개인이 추구하는 궁극적인 가치나 믿음으로 보았다. 즉, 사람의 행동과 의사 결정이 추상적이고 복잡한 이유를 분석하 는 이론으로 인간의 행동과 의사결정에 영향을 미치는 수단 적 속성(attributes)과 그 속성을 통하여 얻게 되는 결과적인 혜 택(consequences), 그리고 이로 인한 궁극적인 목적 상태의 최 종 가치(value)간의 관련성에 대하여 세 가지의 추상적 단계로 구분한 소비자 행동 분석의 질적 연구 방법이다. 여기서 속성 은 상품 자체가 가진 고유한 유, 무형의 특성으로 상품의 선택 시 가장 중요하게 고려되는 직접적인 기능을 말한다. 혜택은 상품의 특성을 인지하고 사용함으로써 야기되는 심리적 또는 기능적 기대 또는 편익이다. 가치는 속성과는 직접적으로 연 관되지 않지만, 혜택을 통해 개인이 가장 근원적인 동기와 옥 구를 반영하는 추상적이며 고차원적인 최종의 목적 상태이다 (Table 1 참조).

이러한 $\mathrm{MEC}$ 이론의 속성, 혜택, 가치 $(\mathrm{A}, \mathrm{C}, \mathrm{V})$ 세 가지 요 소는 단계적으로 상호 연관의 사슬(chain)구조를 형성하며, 구 체적인 상품의 특성을 인지하는 단계로부터 이를 추상적인 개 인의 내적 가치로 연결하는 계층적 흐름을 밝힐 수 있다.

\section{3. 래더링(Laddering) 기법}

$\mathrm{MEC}$ 이론은 소비자 내면구조에 대한 조사방법을 위해 래더

Table 1. Means-end chain model

\begin{tabular}{c|c|c}
\hline Abstract & Value & Terminal/instrumental \\
\hline$\uparrow$ & Consequences & Psychosocial/functional \\
\hline Concrete & Attributes & Abstract/concrete \\
\hline
\end{tabular}

Source: Lee and Ryu, 2018
링 기법이 고안되어, 소비자가 특정의 목적을 위해 사용하는 중요 수단이 어떠한 의미가 있는지에 대한 관계를 확인하고자 할 때 적용하는 방법이다. 여기서 래더(ladder)란 상품과 소비 자의 지각과정 사이의 인과관계를 의미하며, 이를 분석하여 소 비자가 추구하는 목적을 심층적으로 추적해 나간다. 래더링 실 행 방법은 '소프트 래더링 (soft laddering)' 과 '하드 래더링 (hard laddering)'으로 크게 나뉜다(Table 2 참조).

소프트 래더링은 소비자에게 직접적인 질의응답을 수행하는 심층적(in-depth) 인터뷰 기법으로 일련의 $\mathrm{A}, \mathrm{C}, \mathrm{V}$ 사이의 연 계성을 찾기 위해 “그것이 당신에게 왜 중요합니까?”라는 연속 된 질문을 통해 응답자의 인지구조를 래더로 설계하는 기법으 로 기존의 연구가 미진하거나, 새로운 사실 혹은 가설을 발견 할 수 있는 탐색적 연구이다. 그러나 질문자의 면접기법에 전 적으로 의존하게 되므로 숙련된 질문자를 요하며, 장시간의 면 접시간과 많은 조사비용이 소요되는 단점과 큰 규모의 표본이 요구되는 연구에는 한계가 있다(ter Hofstede et al., 1998). 이러 한 한계를 극복하기 위해 고안된 하드 래더링은 선행된 연구 를 통하여 구성된 질문을 제시하여 개별적인 래더 안에서 $\mathrm{A}$, $\mathrm{C}, \mathrm{V}$ 의 관계를 선택하도록 하는 자기 기입식 설문지(survay) 방식 기법으로 그 중, 연계방식기법(APT)의 조사방법이 가장 정교하게 개발되었다(Hwang, 2008). APT 래더링은 고정된 형식의 틀을 이용하여 각각의 $\mathrm{A}, \mathrm{C}, \mathrm{V}$ 사이의 연결을 측정하 는 것으로 대표 표본이 필요한 양적 조사에 이용된다. 보다 객 관적이며, 조사 시간과 비용을 절약과 자료 분석이 비교적 간 단한 장점을 지닌 방법이라 할 수 있다. 그러나 APT 래더링은 사전에 추출하여 표준화한 주요 항목 요소의 제시로 응답 범위 가 제한되는 한계를 가지고 있어, 이를 개선하기 위해서는 $\mathrm{A}$, $\mathrm{C}, \mathrm{V}$ 각 항목에 대한 충분한 '사전조사' 과정이 반드시 있어야 한다(Cha and Kweon, 2013). APT 래더링의 설문 조사내용은 함축매트릭스(Structural Implication Matrix: SIM)의 각 항목 간 연결 빈도 분석표로 작성되어 $\mathrm{A}-\mathrm{C}, \mathrm{C}-\mathrm{V}$ 간의 직 - 간접적인 연관성을 분석한다. 이러한 상호연관의 사슬 결과를 바탕으로 $\mathrm{HVM}$ 의 네트워크형 다이어그램으로 표현되어 최종적으로 $\mathrm{A}$, $\mathrm{C}, \mathrm{V}$ 의 계층적 흐름의 연관관계가 분석된다.

Table 2. Overview of laddering

\begin{tabular}{l|l|l}
\hline Sortation & \multicolumn{1}{|c|}{ Soft laddering } & \multicolumn{1}{c}{ Hard laddering } \\
\hline Purpose & $\begin{array}{l}\text { Lack of existing research, a } \\
\text { search for new facts, apply to } \\
\text { basic research }\end{array}$ & $\begin{array}{l}\text { A study on the objectifi- } \\
\text { cation as a structured ques- } \\
\text { tionnaire }\end{array}$ \\
\hline Method & $\begin{array}{l}\text { Configured based on in-depth } \\
\text { interviews, a study on the sys- } \\
\text { tem of A-C-V }\end{array}$ & $\begin{array}{l}\text { Used as a follow-up to soft } \\
\text { laddering }\end{array}$ \\
\hline Subject & $\begin{array}{l}\text { Intensified research on a small } \\
\text { number(20 30 persons) of sub- } \\
\text { jects }\end{array}$ & $\begin{array}{l}\text { Analysis for a large group } \\
\text { (200 300 persons) }\end{array}$ \\
\hline
\end{tabular}

Source: Lee and Ryu, 2018 
이에 본 연구는 경주 도심 고분의 방문으로 얻게 되는 가치 라는 무형적인 연구 상황을 고려하여 우선, 심층 인터뷰의 탐 색적 연구를 진행하여 $\mathrm{A}, \mathrm{C}, \mathrm{V}$ 항목을 구성하고, 이를 바탕으로 반구조적인 $\mathrm{APT}$ 래더링의 설문조사 통해 보다 객관적인 연구 를 진행하였다. 이를 통해 방문의 대한 $\mathrm{A}, \mathrm{C}, \mathrm{V}$ 간의 관계 및 상호작용의 가치체계 결과를 더욱 명확히 제시하며, 소프트 래 더링의 한계인 공간 · 시간적 문제를 보완하고자 하였다.

\section{4. 관련연구 동향}

$\mathrm{MEC}$ 이론과 관련된 연구는 최근 다양한 분야에서 활발하게 연구가 진행되고 있다. 그 중 관광에 대한 $\mathrm{MEC}$ 이론의 적용연 구(Gutman, 1982), 관광지역 지역주민의 가치체계에 대한 MEC 과 래더링 적용의 타당성 제시(Olson and Reynolds, 1983), 관 광 동기에 대한 속성 항목간의 상관 관계성 연구(Kwon et al., 2012), 탐조객과 전문탐조객의 가치추구 비교분석을 위한 래더 링 방법론 적용의 타당성(Han et al., 2011), 도보관광지의 $\mathrm{MEC}$ 이론 적용을 통한 도보관광 이론적 개념 확립 및 이론 적 용의 적합(Kim et al., 2014) 등의 연구는 $\mathrm{MEC}$ 이론과 래더링 방법론을 적용한 관광 및 여가 활동에 있어 선택 속성과 가치 관계를 혜택의 매개로 분석한 연구 결과는 보다 상세한 연구 대상자의 가치체계 구조와 구체적인 인과관계를 제시함에 있 어 적합한 이론임을 설명하였다. 이러한 연구 방법론을 적용한 연구로 Hwang(2008)은 문화유산관광지 관광자의 관광지 선택 속성과 그에 따른 편익인 결과와 가치의 관계성 및 중요 지각 요인을 규명하여 지역별 문화유산관광의 프로그램 및 공간 개 발 방안 등을 제안하였다. $\mathrm{Kim}$ and $\mathrm{Cho}(2011)$ 는 도보 관광객 이 지각한 가치와 도보관광지 속성간의 관계를 편익이라는 매 개를 통해 관광객의 궁극적 가치를 중심으로 한 관광지 속성의 중요성을 고찰하였고, 이를 통해 차별적인 관광지 속성 강화 전략의 필요성을 시사하였다. Jang(2013)은 문화관광 유형에 따른 문화관광자를 분류하여 그들의 추구 가치체계를 비교 분 석을 통해 문화예술상품의 특성 파악과 문화관광의 방향성을 제 시하였다. Lim and Lee(2013)는 가족단위의 도시공원 이용객에 대한 가치체계를 분석을 통해 도시 공원을 운영함에 있어 가족 단위의 건강한 여가 활동과 행복한 삶의 수준 지원을 위한 공 원계획은 친자연적이고 쉽고 저렴하게 접근방안이 강구되어야 한다는 시사점을 제시하였다. Kwon et al.(2012)은 국립공원 정상등산 탐방객과 둘레길 탐방객의 가치체계 비교 - 분석을 하였으며, 탐방객 공통적으로 자연경관을 통해 자연의 아름다 움을 감상하고, 자연에 대한 관심을 가짐으로써 즐거움과 재미, 자연의 소중함을 느끼는 가치체계를 도출하였다. 이를 통해 둘 레길 조성 시 명상 체험 숲길 조성, 자연생태해설 표지판 등의 둘레길 이용 탐방객 특성을 반영한 시설물 설치 및 해설 프로 그램 개발 제안 및 탐방객수 제한, 탐방객 분산정책 등의 보다
정교한 탐방객 관리시스템 필요성을 입증하였다. 이처럼 관광 지 및 문화유산 관광지에 이용자의 가치체계에 대한 $\mathrm{MEC}$ 이 론 적용 선행연구는 관광지에 대한 선택 속성과 혜택의 결과로 얻게 되는 최종 가치의 가치체계 연구결과를 통해 전략적인 관 광의 마케팅 설정, 프로그램 개발 제안, 시스템 정비 등으로 좀 더 효율적인 자원관리과 활용계획을 제시하였다.

고분에 대한 가치 연구에서는 고고학 유적 및 고분이 지닌 문화유산의 정보-미학-경제적 가치 활용에 대한 방법론적 논의로 이를 통한 활용의 범위와 분야를 구분하였다(Choi, 2016; Lee, 2011; Song, 2012). 하지만 MEC 이론을 적용한 래더링의 탐색적 연구를 바탕으로 관광객과 지역주민이 고분 또는 문화유 산의 방문을 통한 선택 속성, 혜택, 가치와 가치체계를 비교 분석하여 중요 지각 요인을 활용한 문화유산의 활성화 방안제 시의 국내·외 연구사례는 전무한 실정이다. 이에 본 연구에서 는 경주 도심 고분의 방문으로 지역주민과 관광객이 인지하는 다양한 수단으로써의 선택 속성, 그로 인해 얻고자 하는 결과 적인 혜택 그리고 그들이 지향하는 궁극적인 목적 상태인 최종 적 가치의 파악으로 가치에 대한 계층적 인지구조와 하위차원 들 간의 상호 관계성 분석을 통해 '경주 도심 고분공원' 조성에 있어 고분의 역사 - 문화를 활용한 실무적인 조경계획 방안을 모색하였다. 기존의 선행 연구는 지역의 방문객에만 한정하여 진행한 반면, 본 연구에서는 경주 도심에 밀집된 고분의 역사 유적 공간과 고분 주변에 인접한 거주공간에 대한 입지적 특수 성을 고려하여 경주 도심 고분의 방문자를 관광객과 경주 도심 고분을 가까이하고, 고분의 가치를 알고 돌보아야 할 책임이 있 는 지역주민으로 구분하여 연구의 범위를 더욱 확대하였다.

\section{III. 연구내용 및 방법}

\section{1. 연구의 문제 설정}

본 연구는 경주 도심 고분을 방문하는 지역주민과 관광객의 속성, 그에 따른 혜택과 가치의 구성요인의 도출하고, 그들이 얻고자 하는 최종적 가치의 구조적 분석을 SIM과 HVM을 통 해 지역주민과 관광객 각각의 $\mathrm{A}, \mathrm{C}, \mathrm{V}$ 연계성을 도출하고, 두 집단 간의 가치체계 차이를 비교분석한다. 즉, 방문 목적지의 선택 행동에 있어 지역주민과 관광객의 수단적 속성과 최종적 목적 상태인 가치 사이의 연계성 파악에 주된 목적이 있다. 본 연구 목적 달성을 위한 연구의 틀(Figure 2 참조)과 주된 연구 문제는 다음과 같다.

[연구문제 1] $\mathrm{MEC}$ 이론에서 지역주민과 관광객이 중요하게 고려하는 가치구조의 단계별 $\mathrm{A}, \mathrm{C}, \mathrm{V}$ 의 항목 을 밝힌다. 


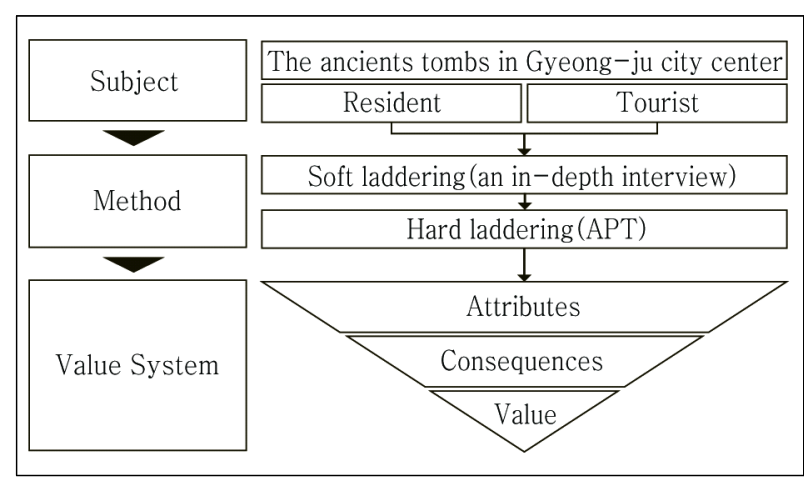

Figure 2. Analysis model of research

[연구문제 2] 지역주민과 관광객의 가치구조의 단계별 A, C, $\mathrm{V}$ 의 항목의 연결 관계를 SIM과 HVM 분석을 통해 밝힌다.

[연구문제 3] 지역주민과 관광객의 가치체계의 구조를 비교 하여 차이점을 밝힌다.

\section{2. 측정변수 설정 및 설문지 구성}

본 연구의 대상 범위는 경주 도심 고분은 사적 제 512 호 대릉 원 일원의 고분으로 경주 노동동 4 기, 노서동 13 기, 황오동 13 기, 황남동 45 기, 인왕동 10 기, 총 85 기로 경주 고도 지구의 역 사환경 특별보존지구내의 고분으로 한정한다. 지역주민은 역사 문화환경 보존육성지구의 동부동, 노동동, 노서동, 황남동, 황 오동, 인왕동, 교동, 사정동(Figure 1 참조)에 거주하며, 생활하 는 지역주민으로 한정하고, 관광객은 경주 도심 고분을 방문하 여 관련 관광 및 체험 활동을 한 관광객으로 한정한다.

속성은 크게 본질적으로 핵심이 되는 속성과 그로 인해 부가 적으로 얻게 되는 부가적 속성 그리고 체험 및 활동적 속성을 포함한다. 핵심적 속성은 기본적으로 고려하는 객관적이고 물 리적인 면으로 주로 연구 위치 자체가 가지고 있는 문화유산 특성 요인이며, 부가적 속성은 핵심적인 속성을 보완하고 강화 되어지는 특성으로 자연 경관, 자원시설, 서비스, 비용, 관광지 연계 등의 요인이다. 마지막으로 체험 및 활동적 속성은 핵심 적, 부가적 속성을 통하여 관련 경험과 행동 등으로 이어지는 행사 및 축제, 휴식 및 휴양 등을 의미한다. 속성은 대상에 대 한 객관적인 개념이라면 혜택은 속성으로 인한 개인적인 결과 로써 주관적 개념이다. 혜택은 비교적 즉각적, 구체적, 감정 적-정서적, 상징적이며, 또한 다른 사람과 상호작용으로 나타 날 수 있는 혜택으로 사회에 관계되거나, 사회성을 통하여 얻 게 되는 옥구와 충족으로 얻게 되는 사회 및 기능적 혜택과 개 인이 고분에 대한 인식과 행동의 습득으로 인하여 얻게 되는 정보, 지식, 교육 등의 관련한 인지적 혜택 그리고 정서나 감정, 분위기, 느낌을 불러일으키는 정서적 혜택을 포함한다. 가치는
경주 도심 고분의 방문자의 옥구를 충족시키기 위해 고분의 속 성에 대하여 취하는 결과적인 혜택으로 나타나는 주관적 - 객 관적 태도로 이곳을 방문하는 동기에 앞서는 사고의 작용을 말 한다. 또한, 경주 도심 고분 방문에 대한 행동의 방향을 결정하 는 이상 및 신념을 의미한다.

경주 도심 고분을 방문하는 지역주민과 관광객의 가치체계 의 비교분석을 위해 본 조사는 구조화된 설문지를 사용하는 하드 래더링의 $\mathrm{APT}$ 래더링을 채택하였다. APT 래더링은 세 부항목 구성에 대한 철저한 사전조사의 권장함에 따라 $\mathrm{A}, \mathrm{C}$, $\mathrm{V}$ 간의 항목 도출을 위해 먼저 현장조사와 관련 선행연구(Jang, 2013; Joo et al., 2006; Lee and Ryu, 2018; Nunkoo and Ramkissoon, 2009; Wassenberg et al., 2015) 자료를 토대로 조 경, 문화유산, 관광, 철학, 건축 관련 전문가와의 브레인스토밍 (brain storming)을 실시하여 1차 A, C, V 항목을 추출하였다. 이후 석·박사학위 소지 및 직업 경력 15년 이상으로 관련 연 구 경험이 있는 조경, 문화유산, 관광, 철학, 건축 전문가 10 인, 경주도심 지역주민 5 인, 관광객 5 인을 대상으로 심층 인터뷰를 실시하여 2차 A, C, V 항목을 추출하였다. 질적 연구의 항목구 성에 대한 타당성 확보를 위해서는 연구 참여자에 의한 연구 결과의 확인(member checking) 또는 연구자간의 교차검증이 필수적이다(Kim and Cho, 2011). 이에 1, 2차 조사항목을 토대 로 1,2 차 조사 참여자 중 박사학위 소지 및 직업 경력 20년 이 상으로 관련 연구 경험이 있는 조경, 관광, 철학 전문가 3 인의 검토 과정을 통한 자문 및 조언을 바탕으로 각 항목의 통합 및 세분화의 수정 단계를 거쳐 본 설문조사 APT 래더링의 최종 속성 12 항목, 혜택 11 항목, 가치 10 항목의 구성을 구조화 시켰 다(Table 3 참조).

\section{3. 연구 자료 수집 및 분석방법}

본 조사 APT 래더링 조사기간은 2018년 11월 15일부터 12 월 20 일까지 약 4 주간 경주 동부동, 노동동, 노서동, 황남동, 황 오동, 인왕동, 교동, 사정동의 거주 지역주민 190 명과 경주 도 심 고분 관광객 190 명, 총 380 명을 대상으로 실시하였다. 조사 결과, 응답을 완전히 마치지 않거나 불성실하게 작성된 지역주 민 24부, 관광객 20 부가 제외되어 최종 지역주민 설문지 166 부, 관광객 설문지 170 부로 총 336 부의 설문지가 분석에 사용되었 다. APT 래더링은 항목 간 연결 관계의 구성 확인과 그 중 가 장 의미 있는 연결 관계를 찾는 분석방식으로, 이를 위해서는 많은 연결 응답률을 보인 관계를 확인하는 빈도분석 방법이 가 장 적절하다. 이에 본 연구의 인구통계사항과 $\mathrm{A}, \mathrm{C}, \mathrm{V}$ 연결 문 항에 대해 빈도 분석을 실시하였다. 수집된 자료는 SPSS Win ver. 22.0 통계패키지를 이용하였으며, SIM 작성에는 Microsoft Excel: 2010과 HVM 작성에는 Visio 2016을 활용하였다. 
Table 3. Hard laddering(APT) attributes - consequences-value category and content code summary

\begin{tabular}{|c|c|}
\hline Sortation & Category \\
\hline $\begin{array}{l}\text { Essential, } \\
\text { additional, } \\
\text { experienced } \\
\text { and active }\end{array}$ & $\begin{array}{l}\text { (A1) A historic place } \\
\text { (A2) A unique culture } \\
\text { (A3) Various ancient tombs } \\
\text { (A4) Educational and learning places } \\
\text { (A5) A traditional way of life } \\
\text { (A6) A traditional landscape } \\
\text { (A7) Festivals and events } \\
\text { (A8) Link to other tourist destinations } \\
\text { (A9) Rest and take a walk } \\
\text { (A10) A place for contemplation } \\
\text { (A11) Novel experience } \\
\text { (A12) Recollections of past memories }\end{array}$ \\
\hline $\begin{array}{l}\text { Social and functional, } \\
\text { cognitive, } \\
\text { emotional }\end{array}$ & $\begin{array}{l}\text { (C1) Acquisition of knowledge and information } \\
\text { (C2) Understanding of local area } \\
\text { (C3) A historical lesson } \\
\text { (C4) Various cultural experiences } \\
\text { (C5) A feeling of an ancient taste and unique spirit } \\
\text { (C6) Relieve stress } \\
\text { (C7) Develop a bond } \\
\text { (C8) An opportunity for new memories } \\
\text { (C9) Time for reflection and awakening } \\
\text { (C10) Save time and money on tourism } \\
\text { (C11) Expressions through works(letters, photographs, } \\
\text { pictures, etc) }\end{array}$ \\
\hline $\begin{array}{l}\text { Value } \\
\text { (V) }\end{array}$ & $\begin{array}{l}\text { (V1) Aesthetic beauty } \\
\text { (V2) The attainment of the purpose of learning } \\
\text { (V3) A solution for curiosity } \\
\text { (V4) Improvement of historic and cultural cultivation } \\
\text { (V5) Sense of belonging and identity } \\
\text { (V6) Self-reflection and healing } \\
\text { (V7) Self-respect } \\
\text { (V8) A lively way of being } \\
\text { (V9) Fun and joy } \\
\text { (V10) An amicable relationship }\end{array}$ \\
\hline
\end{tabular}

\section{IV. 연구결과}

\section{1. 응답자의 특성}

조사 응답자의 인구 통계적 특성은 Table 4 와 같고, 성별은 전체 여성의 비율이 $65.1 \%$ 로 남성 $(34.9 \%)$ 에 비해 높았으며, 지역주민 $(62.7 \%)$ 과 관광객 $(67.5 \%)$ 에서도 여성의 비율이 상대 적으로 높았다. 전체 연령에서는 40대(29.6\%), 50대(20.6\%), 60 대 이상 $(21.2 \%)$ 의 순으로 응답자의 $71.4 \%$ 가 40 대 이상이었 으며, 지역주민의 경우는 20,30 대가 $15.0 \%$ 에 그친 반면, 관광 객의 경우는 $42.0 \%$ 로 나타나 상대적으로 관광객의 연령층이 낮은 것으로 나타났다. 지역주민의 연구 대상지는 70 년대 이후 부터 조성된 1 종 일반 주거지와 일반 상업지역의 기존 거주민 으로 대상지 특성상 연령층이 40대 이상에 집중되어 있으며, 최근 황남동의 황리단길, 노동 - 노서동의 봉황대 주변 주말 야 외음악행사, 프리마켓, 푸드 트럭 행사 등 젊은 세대들을 겨낭 한 문화 컨텐츠 활성화로 인해 20,30 대의 관광객 유입이 이루 어짐으로 파악된다. 방문동행자에서는 전체 가족(44.5\%) 단위 가 높게 나왔으며, 지역주민은 가족(42.8\%), 친구/연인(19.3\%),
Table 4. Demographic characteristics

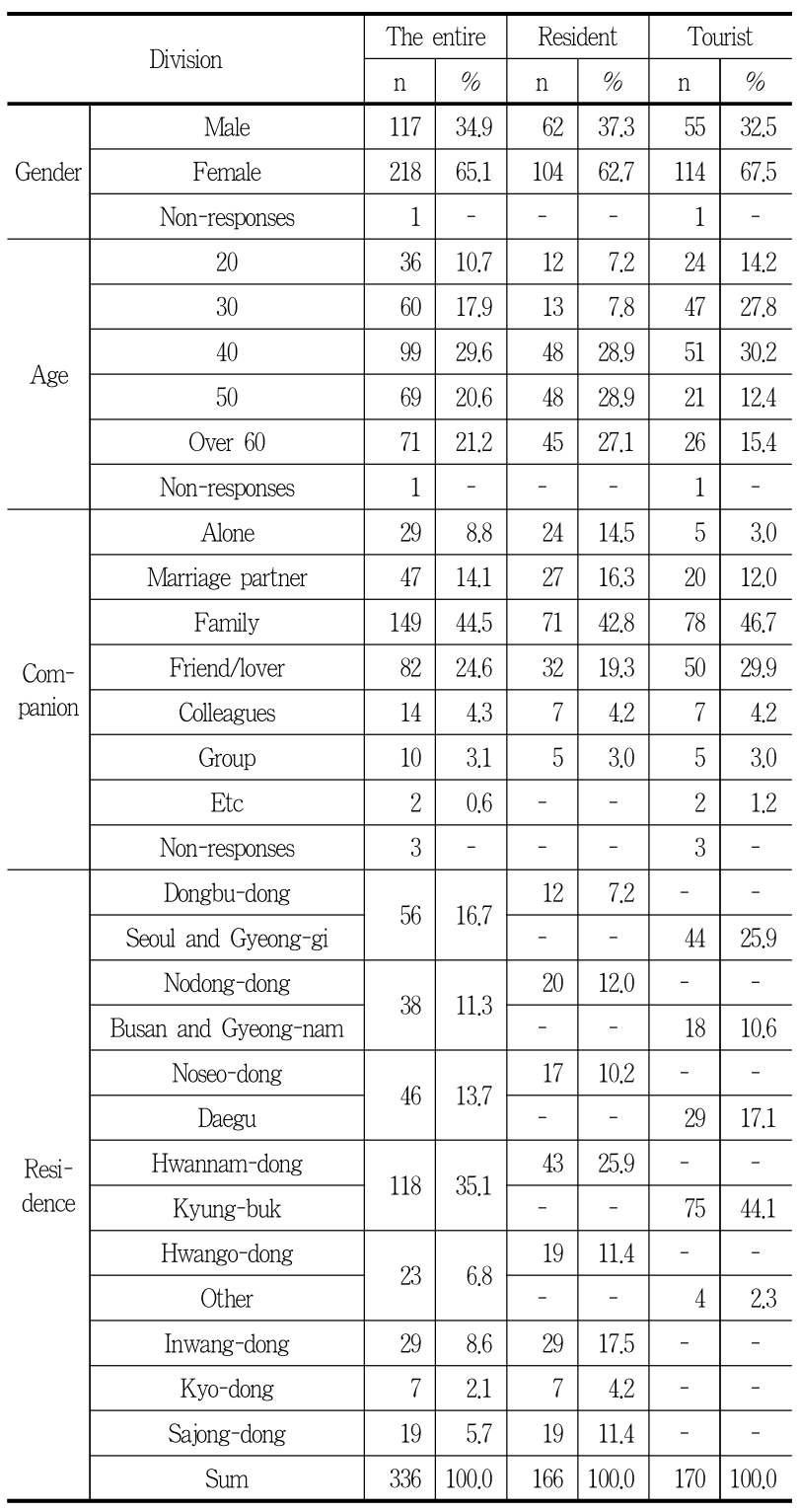

배우자 $(16.3 \%)$ 순이며, 관광객 또한 가족 $(46.7 \%)$, 친구/연인 (29.9\%), 배우자 $(12.0 \%)$ 순으로 그 중 관광객이 지역주민에 비 해 혼자 경주 도심 고분을 방문하는 비율은 상대적으로 낮은 것으로 조사되었다. 거주지역의 지역주민은 황남동(25.9\%), 인 왕동 $(17.5 \%)$, 노동동 $(12.0 \%)$ 과 관광객은 경북 $(44.1 \%)$ 이 가장 높게 나타났다. 이는 일반 주거지역의 황남동, 인왕동, 노동동 과 경북의 위치는 지리적 접근성의 용이함으로 인해 나타난 결 과로 파악된다.

\section{2. 함축매트릭스(SIM)}

1) 지역주민의 속성-혜택 $(\mathrm{A}-\mathrm{C})$ 간 연결 관계

$\mathrm{SIM}$ 은 $\mathrm{A}, \mathrm{C}, \mathrm{V}$ 간 직 · 간접 관련성을 파악하기 위해 $\mathrm{A}-\mathrm{C}$, 
Table 5. Frequency of hard laddering connection between attributesconsequences

(resident, $n=166$ )

\begin{tabular}{|c|c|c|c|c|c|c|c|c|c|c|c|c|c|}
\hline \multirow{2}{*}{\multicolumn{2}{|c|}{ Sortation }} & \multicolumn{12}{|c|}{ Consequences } \\
\hline & & \multirow{2}{*}{$\frac{\mathrm{C} 1}{23}$} & \multirow{2}{*}{$\begin{array}{l}\mathrm{C} 2 \\
42 \\
\end{array}$} & \multirow{2}{*}{$\begin{array}{c}\mathrm{C} 3 \\
36 \\
\end{array}$} & \multirow{2}{*}{\begin{tabular}{c|}
$\mathrm{CA}$ \\
24 \\
\end{tabular}} & \multirow{2}{*}{$\begin{array}{r}\mathrm{C} 5 \\
30 \\
\end{array}$} & & \multirow{2}{*}{$\begin{array}{ll}\mathrm{C} 7 \\
10\end{array}$} & \multirow{2}{*}{$\frac{\mathrm{C} 8}{16}$} & \multirow{2}{*}{$\begin{array}{r}\text { C9 } \\
8 \\
\end{array}$} & \multirow{2}{*}{\begin{tabular}{|c|}
$\mathrm{C} 10$ \\
4
\end{tabular}} & \multirow{2}{*}{\begin{tabular}{|c|}
$\mathrm{C} 11$ \\
1
\end{tabular}} & \multirow{2}{*}{\begin{tabular}{|c|} 
계 \\
236
\end{tabular}} \\
\hline \multirow{12}{*}{$\begin{array}{l}\text { Attri- } \\
\text { butes }\end{array}$} & $\mathrm{A} 1$ & & & & & & & & & & & & \\
\hline & A2 & 4 & 25 & 11 & 9 & 12 & 17 & 4 & 6 & 5 & - & - & 93 \\
\hline & A3 & 8 & 9 & 9 & 6 & 9 & 9 & 5 & 7 & 2 & 3 & - & 67 \\
\hline & A4 & 26 & 26 & 21 & 9 & 12 & 26 & 3 & 7 & 6 & 1 & - & 137 \\
\hline & A5 & - & 7 & 4 & 1 & 6 & 4 & 2 & 3 & 2 & - & - & 29 \\
\hline & A6 & 3 & 10 & 3 & 2 & 14 & 16 & 1 & 6 & 2 & - & - & 57 \\
\hline & A7 & 12 & 38 & 21 & 28 & 20 & 47 & 13 & 23 & 7 & 4 & 2 & 215 \\
\hline & A8 & 1 & 3 & 1 & 3 & 4 & 7 & - & 2 & - & 2 & - & 23 \\
\hline & A9 & 19 & 42 & 26 & 21 & 32 & 75 & 8 & 22 & 19 & 3 & - & 267 \\
\hline & A10 & 7 & 15 & 5 & 3 & 10 & 26 & 1 & 10 & 18 & 6 & 1 & 102 \\
\hline & A11 & 5 & 9 & 4 & 5 & 5 & 16 & 1 & 16 & 3 & 7 & 1 & 72 \\
\hline & A12 & 3 & 3 & 6 & 4 & 4 & 4 & 3 & 8 & 8 & 3 & 1 & 47 \\
\hline \multicolumn{2}{|c|}{ Sum } & 111 & 229 & 147 & 115 & 158 & 289 & 51 & 126 & 80 & 33 & 6 & 1,345 \\
\hline
\end{tabular}

$\mathrm{C}-\mathrm{V}$ 간의 교차분석을 실시하여 각각의 연결빈도를 확인한다. 지역주민 A-C간의 SIM은 Table 5 와 같다. 가장 중요하게 고 려하는 A-C 연결 관계는 '휴식(휴양) 및 산책(A9)-스트레스 해소(C6)'로 총 75 회의 직접적인 연결 관계로 나타났다. 다음 으로 '축제 및 행사(A7)-스트레스 해소(C6)' 47회, '역사적 장 소(A1)-지역에 대한 이해(C2)와 스트레스 해소(C6)'와 '휴식 (휴양) 및 산책(A9)-지역에 대한 이해(C2)'와 각각 42회의 직 접적인 연결 관계로 나타났다. 또한, 응답이 집중되는 선택 속 성 항목은 '휴식(휴양) 및 산책(A9)' 267회, '역사적 장소(A1)' 236회, '축제 및 행사(A7)' 215회의 높은 연결빈도로 나타나, 이 는 지역주민이 경주 도심 고분 방문 시 가장 고려하는 수단임 을 알 수 있다. 혜택은 '스트레스 해소(C6)' 289회로 가장 높은 연결빈도를 보였고, '지역에 대한 이해(C2)' 229회, '옛 정취와 얼을 느낌(C5)' 158 회의 높은 연결빈도가 나타났다.

\section{2) 관광객의 속성-혜택 $(\mathrm{A}-\mathrm{C})$ 간 연결 관계}

관광객 A-C간의 SIM은 Table 6 과 같다. 가장 중요하게 고 려하는 A-C 연결 관계는 '휴식(휴양) 및 산책(A9)-스트레스 해소(C6)'로 총 65 회의 직접적인 연결 관계로 나타났다. 다 음으로 '교육· 학습적 장소 $(\mathrm{A} 4)$-지식 · 정보 습득 $(\mathrm{Cl})$ ' 50 회 '역사적 장소(A1)-지역에 대한 이해(C2)' 45 회, '역사적 장소 (A1)-지식 · 정보 습득 $(\mathrm{Cl})$ 과 스트레스 해소 $(\mathrm{C6})^{\prime}$ 가 각각 44 회 의 직접적인 연결 관계로 나타났다. 또한, 응답이 집중되는 선 택 속성 항목은 '역사적 장소(A1)' 261회, '휴식(휴양) 및 산책 (A9)' 250회, '교육· 학습적 장소(A4)' 219회의 높은 연결빈도 로 나타나, 이는 관광객이 경주 도심 고분 방문 시 가장 고려하 는 수단임을 알 수 있다. 혜택은 '스트레스 해소(C6)' 268회로 가장 높은 연결빈도를 보였고, '지역에 대한 이해(C2)' 214회,
Table 6. Frequency of hard laddering connection between attributesconsequences

(tourist, $n=170$ )

\begin{tabular}{|c|c|c|c|c|c|c|c|c|c|c|c|c|c|}
\hline \multirow{2}{*}{\multicolumn{2}{|c|}{ Sortation }} & \multicolumn{12}{|c|}{ Consequences } \\
\hline & & $\mathrm{Cl}$ & $\mathrm{C} 2$ & $\mathrm{C} 3$ & $\mathrm{CA}$ & $\mathrm{C} 5$ & $\mathrm{C} 6$ & $\mathrm{C} 7$ & $\mathrm{C} 8$ & C9 & $\mathrm{C} 10$ & $\mathrm{C} 11$ & 계 \\
\hline \multirow{12}{*}{$\begin{array}{l}\text { Attri- } \\
\text { butes }\end{array}$} & Al & 44 & 45 & 35 & 30 & 39 & 44 & 5 & 13 & 3 & 3 & - & 261 \\
\hline & A2 & 15 & 27 & 20 & 17 & 26 & 22 & 3 & 5 & 2 & 2 & - & 139 \\
\hline & A3 & 16 & 15 & 13 & 13 & 26 & 17 & 2 & 4 & 2 & - & - & 108 \\
\hline & A4 & 50 & 34 & 30 & 27 & 32 & 33 & 1 & 7 & 5 & - & - & 219 \\
\hline & A5 & 2 & 3 & 7 & 2 & 5 & 5 & 2 & 2 & 1 & - & - & 29 \\
\hline & A6 & 14 & 18 & 5 & 9 & 17 & 13 & 2 & 2 & 2 & 2 & - & 84 \\
\hline & A7 & 18 & 19 & 11 & 21 & 11 & 28 & 4 & 13 & 2 & 4 & - & 131 \\
\hline & A8 & 1 & 2 & 1 & 1 & 4 & 2 & 1 & 3 & - & 1 & - & 16 \\
\hline & A9 & 35 & 34 & 26 & 21 & 36 & 65 & 1 & 19 & 10 & 3 & - & 250 \\
\hline & A10 & 3 & 6 & 2 & 2 & 5 & 9 & 1 & 4 & 2 & 1 & - & 35 \\
\hline & A11 & 9 & 10 & 8 & 5 & 5 & 23 & - & 20 & 3 & 4 & - & 87 \\
\hline & A12 & 2 & 1 & 5 & 4 & 5 & 7 & 1 & 5 & 1 & - & - & 31 \\
\hline \multicolumn{2}{|c|}{ Sum } & 209 & 214 & 163 & 152 & 211 & 268 & 23 & 97 & 33 & 20 & - & 1,390 \\
\hline
\end{tabular}

‘옛 정취와 얼을 느낌(C5)' 211회, '지식·정보 습득(C1)' 209 회의 높은 연결빈도가 나타났다.

\section{3) 지역주민의 혜택-가치 $(C-V)$ 간 연결 관계}

지역주민 C-V간의 SIM은 Table 7과 같다. 가장 중요하게 고 려하는 C-V 연결 관계는 '스트레스 해소(C6)-역사 · 문화 보호 의식 배양(V4)'으로 총 63회의 직접적인 연결 관계로 나타났 다. 다음으로 '스트레스 해소(C6)-자기 성찰 및 치유(V6)', 58 회, '스트레스 해소(C6)-활기찬 삶(V8)' 55 회, '지역에 대한 이 해(C2)-역사· 문화 보호 의식 배양(V4)' 54 회의 직접적인 연 결 관계로 나타났다. 또한, 응답이 집중되는 혜택 항목은 '스트 레스 해소(C6)' 284회, '지역에 대한 이해(C2) 225회'의 높은 연

Table 7. Frequency of hard laddering connection between consequences-value (resident, $n=166$ )

\begin{tabular}{|c|c|c|c|c|c|c|c|c|c|c|c|c|}
\hline \multirow{2}{*}{\multicolumn{2}{|c|}{ Sortation }} & \multicolumn{11}{|c|}{ Value } \\
\hline & & V1 & $\mathrm{V} 2$ & V3 & V4 & V5 & V6 & V7 & V8 & V9 & V10 & 계 \\
\hline \multirow{11}{*}{$\begin{array}{l}\text { Conse- } \\
\text { quences }\end{array}$} & $\mathrm{Cl}$ & 2 & 17 & 12 & 26 & 9 & 16 & 3 & 10 & 13 & - & 108 \\
\hline & $\mathrm{C} 2$ & 7 & 14 & 9 & 54 & 23 & 39 & 2 & 40 & 36 & 1 & 225 \\
\hline & C3 & 2 & 14 & 10 & 37 & 13 & 27 & 1 & 22 & 15 & - & 141 \\
\hline & $\mathrm{C} 4$ & 3 & 7 & 8 & 28 & 7 & 24 & 3 & 17 & 17 & - & 114 \\
\hline & C5 & 5 & 7 & 4 & 40 & 20 & 32 & 1 & 19 & 23 & - & 151 \\
\hline & $\mathrm{C} 6$ & 8 & 12 & 16 & 63 & 21 & 58 & 6 & 55 & 42 & 3 & 284 \\
\hline & C7 & 1 & 1 & 2 & 14 & 8 & 11 & 2 & 7 & 5 & - & 51 \\
\hline & $\mathrm{C} 8$ & 3 & 6 & 1 & 27 & 9 & 28 & 5 & 22 & 22 & 2 & 125 \\
\hline & C9 & 1 & 2 & 4 & 15 & 4 & 24 & 2 & 9 & 8 & - & 69 \\
\hline & $\mathrm{Cl0}$ & - & 1 & - & 3 & - & 8 & 4 & 6 & 4 & 3 & 29 \\
\hline & C11 & - & - & - & 1 & - & 2 & - & 1 & 1 & - & 5 \\
\hline \multicolumn{2}{|l|}{ Sum } & 32 & 81 & 66 & 308 & 114 & 269 & 29 & 208 & 186 & 9 & 1,302 \\
\hline
\end{tabular}


결빈도를 보였으며, 가치는 '역사· 문화 보호 의식 배양( $(\mathrm{V} 4)$ ' 308 회로 가장 높은 연결빈도를 보였고, '자기 성찰 및 치유 (V6)' 269회, '활기찬 삶(V8)' 208회에 높은 연결 빈도로 나타 났다.

\section{4) 관광객의 혜택-가치 $(\mathrm{C}-\mathrm{V})$ 간 연결 관계}

관광객 C-V간의 SIM은 Table 8과 같다. 가장 중요하게 고 려하는 $\mathrm{C}-\mathrm{V}$ 연결 관계는 '스트레스 해소(C6)-자기 성찰 및 치 유 $(\mathrm{V} 6)^{\prime}$ 로 총 58회의 직접적인 연결 관계로 나타났다. 다음으 로 '옛 정취와 얼을 느낌(C5)-역사· 문화 보호 의식 배양(V4)' 49회, '스트레스 해소(C6)-역사 · 문화 보호 의식 배양(V4)' 48 회, '스트레스 해소(C6)-활기찬 삶 $(\mathrm{V} 8)$ '와 '지식 · 정보 습득 (C1)-역사 · 문화 보호 의식 배양 $(\mathrm{V} 4)^{\prime}$ 이 각각 47 회의 직접적 인 연결 관계로 나타났다. 또한, 응답이 집중되는 혜택 항목은 '스트레스 해소(C6)' 258회, '지역에 대한 이해(C2)' 212회, '지 식·정보 습득(C1)' 207회, '옛 정취와 얼을 느낌(C5)' 206회의

Table 8. Frequency of hard laddering connection between consequences-value

(tourist, $n=170$ )

\begin{tabular}{|c|c|c|c|c|c|c|c|c|c|c|c|c|}
\hline \multirow{2}{*}{\multicolumn{2}{|c|}{ Sortation }} & \multicolumn{11}{|c|}{ Value } \\
\hline & & \multirow{2}{*}{$\begin{array}{r}\mathrm{V} 1 \\
8 \\
\end{array}$} & \multirow{2}{*}{$\frac{\mathrm{V} 2}{35}$} & \multirow{2}{*}{$\begin{array}{l}\mathrm{V} 3 \\
36\end{array}$} & \multirow{2}{*}{$\begin{array}{l}\mathrm{V} 4 \\
47\end{array}$} & \multirow{2}{*}{$\begin{array}{l}\mathrm{V} 5 \\
12 \\
\end{array}$} & \multirow{2}{*}{\begin{tabular}{|l|}
$\mathrm{V} 6$ \\
25 \\
\end{tabular}} & \multirow{2}{*}{$\begin{array}{c}\text { V7 } \\
1\end{array}$} & \multirow{2}{*}{$\begin{array}{r}\mathrm{V} 8 \\
25\end{array}$} & \multirow{2}{*}{$\begin{array}{l}\text { V9 } \\
18\end{array}$} & \multirow{2}{*}{$\frac{\mathrm{V} 10}{-}$} & \multirow{2}{*}{\begin{tabular}{|c|} 
계 \\
207
\end{tabular}} \\
\hline \multirow{11}{*}{$\begin{array}{l}\text { Conse- } \\
\text { quences }\end{array}$} & $\mathrm{Cl}$ & & & & & & & & & & & \\
\hline & $\mathrm{C} 2$ & 13 & 26 & 24 & 44 & 15 & 39 & - & 26 & 25 & - & 212 \\
\hline & C3 & 10 & 33 & 14 & 35 & 11 & 25 & - & 17 & 16 & - & 161 \\
\hline & $\mathrm{C} 4$ & 12 & 18 & 15 & 39 & 7 & 23 & 3 & 20 & 15 & - & 152 \\
\hline & $\mathrm{C5}$ & 8 & 30 & 19 & 49 & 21 & 35 & 3 & 25 & 16 & - & 206 \\
\hline & C6 & 8 & 31 & 16 & 48 & 13 & 58 & 4 & 47 & 33 & - & 258 \\
\hline & C7 & 3 & 1 & 1 & 7 & 2 & 4 & 1 & 4 & 3 & - & 26 \\
\hline & $\mathrm{C} 8$ & 3 & 8 & 8 & 11 & 2 & 23 & - & 19 & 18 & - & 92 \\
\hline & C9 & 2 & 6 & 3 & 2 & 2 & 10 & - & 4 & 2 & & 31 \\
\hline & $\mathrm{C} 10$ & 1 & 2 & - & 1 & - & 5 & 1 & 5 & 5 & - & 20 \\
\hline & C11 & - & - & - & - & - & & - & - & - & - & - \\
\hline \multicolumn{2}{|c|}{ Sum } & 68 & 190 & 136 & 283 & 85 & 247 & 13 & 192 & 151 & - & 1,365 \\
\hline
\end{tabular}

높은 연결빈도를 보였으며, 가치는 '역사· 문화 보호 의식 배양 (V4)' 283회로 가장 높은 연결빈도를 보였고, '자기 성찰 및 치 유(V6)' 247회, '활기찬 삶(V8)' 192회, '학문적 목적 달성(V2)' 190 회에 높은 연결 빈도로 나타났다.

\section{3. 컷-오프(cut-off)의 설정에 따른 통계량 분석}

컷-오프는 HVM에서 두 개의 요소가 연계되었다고 언급되 어짐에 있어 최소한의 횟수로써, 컷-오프 수준을 낮춰 설정할 경우 많은 정보를 얻을 수는 있으나, HVM이 복잡하게 되어 해석이 어렵게 되고, 반대로 컷-오프 수준을 높이 설정한다면 $\mathrm{HVM}$ 의 표현이 단순해져 정보의 많은 부분을 잃게 된다. 따라 서 $\mathrm{HVM}$ 의 작성을 위한 $\mathrm{APT}$ 래더링의 컷-오프 수준 설정을 위해서는 가치의 추상성을 가장 중요하게 고려하여 적당한 기 준점을 결정하는 것이 중요하다. 컷-오프 수준 설정은 확립된 기준에 의하지 않고, 응답자의 수 혹은 연관성의 정도 등 연구 상황에 다르게 제시되고 있다(Han, 2007). 이에 본 연구는 가 치의 수와 지배적 경향성을 중심으로 총 연계수에서 활성화 연계수의 비율을 $50 \%$ 에서 상회하도록 조정하였으며(Jang, 2013), A-C-V의 비율이 추상화의 상태로서 충분히 반영되었 는지도 중요하게 고려하였다. 이와 같은 기준을 중심으로 지역 주민, 관광객에 대한 컷-오프 수준을 설정하였으며, 기준표는 Table 9 와 같다.

먼저, 지역주민 활성화 셀 수는 214개며, 1회 이상 선택된 래 더의 수는 2,647개로 나타났다. 컷-오프 수준이 23인 경우, 활성 화 셀 수는 39 개로 1 회 이상 선택된 셀에서 약 $16 \%$ 를 나타내 며, 활성화 연계수도 총 2,657개 중에서 1,363개로 약 $51 \%$ 를 나 타내고 있다. 반면, 관광객 활성화 셀 수는 198 개며, 1 회 이상 선택된 래더의 수는 2,755 개로 나타났다. 컷-오프 수준이 26 인 경우 활성화 셀 수는 39 개로 1회 이상 선택된 셀에서 약 $16 \%$ 를 나타내며, 활성화 연계수도 총 2,755개 중에서 1,437 개로 약 $52 \%$ 를 나타내고 있다.

(cut-off of resident $=23$ and cut-off of tourist $=26$ )

Table 9. Cut-off of hard laddering decision standard statistic

\begin{tabular}{c|c|c|c|c|c|c}
\hline \multirow{2}{*}{ Sortation } & $\begin{array}{c}\text { Level of } \\
\text { cut-off }\end{array}$ & $\begin{array}{c}\text { Number of } \\
\text { active cells(n) }\end{array}$ & $\begin{array}{c}\text { Cell activation / } \\
\text { total cells(\%) }\end{array}$ & $\begin{array}{c}\text { Total number } \\
\text { of cells }\end{array}$ & $\begin{array}{c}\text { Number of } \\
\text { activation links(n) }\end{array}$ & $\begin{array}{c}\text { Number of activation links/ } \\
\text { total number of links(\%) }\end{array}$ \\
\hline \multirow{5}{*}{ Resident } & 1 & 214 & 0.88 & 1.00 & 2,647 & 1.00 \\
\cline { 2 - 7 } & 21 & 47 & 0.19 & .22 & 1,535 & 0.58 \\
\cline { 2 - 7 } & 22 & 43 & 0.18 & .20 & 1,451 & 0.55 \\
\cline { 2 - 7 } & 23 & 39 & 0.16 & .18 & 1,363 & 0.51 \\
\hline \multirow{5}{*}{ Tourist } & 24 & 35 & 0.14 & .16 & 1,271 & 0.48 \\
\cline { 2 - 7 } & 24 & 198 & 0.82 & 1.00 & 2,755 & 1.00 \\
\cline { 2 - 7 } & 25 & 45 & 0.19 & 0.23 & 1,586 & 0.58 \\
\cline { 2 - 7 } & 26 & 44 & 0.18 & 0.22 & 1,562 & 0.57 \\
\hline
\end{tabular}




\section{4. 가치단계도(HVM)}

SIM을 바탕으로 모든 행과 열의 요소로 이어지는 횟수의 빈 도를 일정 컷-오프 이상의 관계들로 순차적으로 연결하여 가 치사슬로 재구성한 $\mathrm{A}-\mathrm{C}-\mathrm{V}$ 연결 관계의 $\mathrm{HVM}$ 구성을 통해 속 성에서 혜택, 가치에 이르는 일련의 연결과정을 쉽게 파악한다. 또한, 직 · 간접관계의 수를 고려하여 숫자가 높을수록 각 변수 간의 연결 관계를 굵은 선으로 표시하고, 연결 빈도수는 숫자로 표기하여 인지 및 가치구조를 보다 명확하게 표현한다. HVM 는 속성에서 혜택을 거쳐 가치까지 연결되는 핵심적인 가치체 계 연결 관계만으로 구성된다.

\section{1) 지역주민의 HVM 분석}

경주 도심 고분 방문에 있어 지역주민의 $\operatorname{HVM}$ (Figure 2 참조)에서 가장 중요하게 고려하는 속성, 혜택 가치의 항목은 Table 10으로 조사되었다. 또한, HVM의 A-C-V 구조를 살펴 보면 크게 세 가지 가치사슬로 구성되는 것으로 나타났다. 첫 번째로 가장 강한 $\mathrm{A}-\mathrm{C}-\mathrm{V}$ 연결 관계를 보인 가치사슬은 '휴식 (휴양) 및 산책(A9)-스트레스 해소(C6)-역사· 문화 보호 의식 배양(V4)'으로 나타났다. 두 번째로는 '역사적 장소(A1)-지역 에 대한 이해(C2)-역사 - 문화 보호의식 배양(V4)', 세 번째로 는 역사적 장소(A1)-스트레스 해소(C6)-역사· 문화 보호의식 배양(V4)'로 나타났다. 이러한 결과를 종합해 볼 때, 지역주민 의 가치 구조 및 $\mathrm{HVM}$ 는 경주 도심 고분 방문에 있어 선택 속성으로 '휴식(휴양) 및 산책(A9)'과 '역사적 장소(A1)'를 가 장 중요한 수단으로 고려하고 있음을 알 수 있었다. 그리고 그 에 따른 '스트레스 해소(C6)'와 '지역에 대한 이해(C2)'의 혜택 을 경험함으로써 최종 목적 상태인 '역사 - 문화 보호의식 배양 $(\mathrm{V} 4)^{\prime}$ 에 가장 중요한 가치를 두고 있는 것으로 나타났다.

\section{2) 관광객의 $\mathrm{HVM}$ 분석}

경주 도심 고분 방문에 있어 관광객의 $\mathrm{HVM}$ (Figure 3 참조)

Table 10. Comparative analysis of HVM(resident and tourist)

\begin{tabular}{|c|c|c|}
\hline Sortation & Resident & Tourist \\
\hline $\begin{array}{l}\text { Concentrated } \\
\text { Attribute } \\
\text { Top Items }\end{array}$ & $\begin{array}{l}\text { 1. Rest and take a walk(A9) } \\
\text { 2. A historic place(A1) } \\
\text { 3. Festivals and events(A7) }\end{array}$ & $\begin{array}{l}\text { 1. A historic place(A1) } \\
\text { 2. Rest and take a walk(A9) } \\
\text { 3. Educational and learning places } \\
\text { (A4) }\end{array}$ \\
\hline $\begin{array}{l}\text { Concentrated } \\
\text { Consequences } \\
\text { Top Items }\end{array}$ & \multicolumn{2}{|c|}{$\begin{array}{l}\text { 1. Relieve stress }(\mathrm{C} 6) \\
\text { 2. Understanding of local area(C2) } \\
\text { 3. A feeling of an ancient taste and unique spirit(C5) }\end{array}$} \\
\hline $\begin{array}{l}\text { Concentrated } \\
\text { Value } \\
\text { Top Items }\end{array}$ & \multicolumn{2}{|c|}{$\begin{array}{l}\text { 1. Improvement of historic and cultural cultivation(V4) } \\
\text { 2. Self-reflection and healing(V6) } \\
\text { 3. A lively way of being(V8) }\end{array}$} \\
\hline $\begin{array}{l}\text { Concentrated } \\
\text { A-C-V } \\
\text { Top Items }\end{array}$ & $\begin{array}{l}\text { 1. Rest and take a walk(A9) } \\
\text { 2. Relieve stress(C6) } \\
\text { 3. Improvement of historic and } \\
\text { cultural cultivation(V4) }\end{array}$ & $\begin{array}{l}\text { 1. Rest and take a walk(A9) } \\
\text { 2. Relieve stress(C6) } \\
\text { 3. Self-reflection and Healing(V6) }\end{array}$ \\
\hline
\end{tabular}

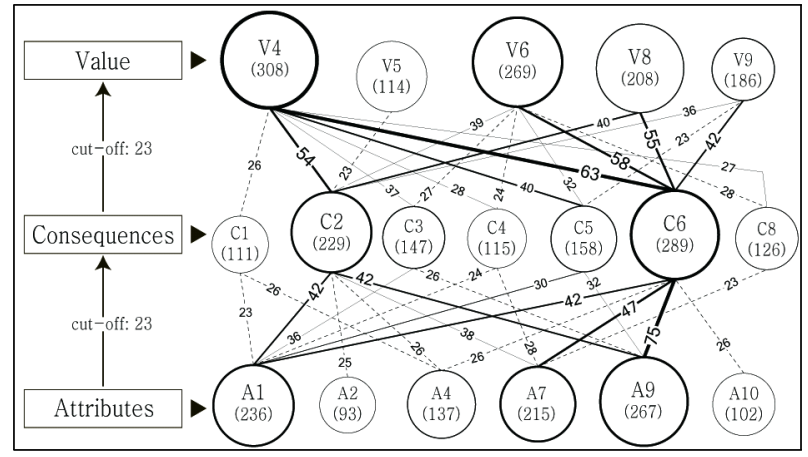

Figure 2. HVM of residents regarding ancient tombs in Gyeong-ju city center

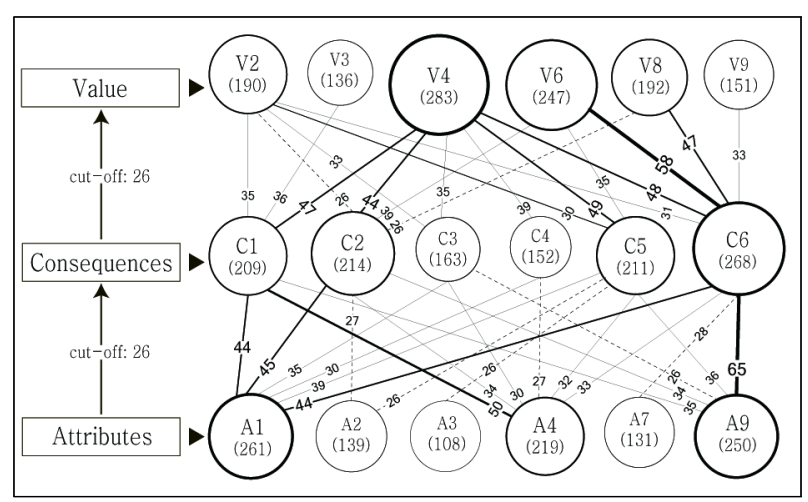

Figure 3. HVM of tourists regarding ancient tombs in Gyeong-ju city center

에서 가장 중요하게 고려하는 속성, 혜택 가치의 항목은 Table 10 으로 조사되었다. 또한, $\mathrm{HVM}$ 의 A-C-V 구조를 살펴보면 크 게 두 가지 가치사슬로 구성되는 것으로 나타났다. 첫 번째로, 가장 강한 $\mathrm{A}-\mathrm{C}-\mathrm{V}$ 연결 관계를 보인 가치사슬은 '휴식(휴양) 및 산책(A9)-스트레스 해소(C6)-자기 성찰 및 치유(V6)'로 나타났다. 두 번째로는, '역사적 장소(A1)-지역에 대한 이해 (C2)-역사· 문화 보호의식 배양 $(\mathrm{V} 4)^{\prime}$ 으로 나타났다. 이러한 결과를 종합해 볼 때, 관광객의 가치 구조 및 $\mathrm{HVM}$ 는 경주 도 심 고분 방문에 있어 선택 속성으로 '휴식(휴양) 및 산책(A9)' 과 '역사적 장소(A1)'를 가장 중요한 수단으로 고려하고 있음 을 알 수 있었다. 그리고 그에 따른 '스트레스 해소(C6)'와 '지 역에 대한 이해(C2)'의 혜택을 경험함으로써 최종 목적 상태인 '자기 성찰 및 치유(V6)'와 '역사· 문화 보호의식 배양 $(\mathrm{V} 4)$ '에 가장 중요한 가치를 두고 있는 것으로 나타났다.

\section{V. 결론 및 논의}

본 연구는 경주 도심 고분 인근에 거주하는 지역주민과 관광 객을 대한 경주 도심 고분의 방문에 관련한 심층적 동기와 가 치 인지구조를 살펴봄으로써 경주시 역사문화도시조성사업의 
일환으로 추진 중인 '경주 도심 고분공원' 조성사업 계획에 대 한 기초자료 제공 및 역사·문화자원 활용계획 방안의 시사점 을 제공하고자 하였다. 특히 지역주민과 관광객의 고분 방문이 어떠한 선택 속성을 가장 중요하게 고려하는 수단이며, 그로 인한 결과적으로 나타나는 혜택 그리고 최종적인 목적 상태의 가치에 대한 인지구조를 밝히기 위해 MEC 이론을 기반으로 래더링 방법론을 적용하여 연구하였다. 본 연구의 결과를 바탕 으로 다음과 같이 논의하고자 한다.

먼저, 경주 도심 고분의 방문에 가장 중요하게 고려하는 선 택 속성으로 지역주민과 관광객 모두 ‘휴식(휴양) 및 산책', '역 사적 장소'가 도출되었고, 이 외에도 지역주민은 '축제 및 행사' 와 관광객은 '교육·학습적 장소'로 조사되었다. 그리고 속성으 로부터 결과적으로 얻게 되는 혜택은 지역주민과 관광객 모두 '스트레스 해소', '지역에 대한 이해', '옛 정취와 얼을 느낌'으로 조사되었다. 마지막 최종 가치는 '역사 - 문화 보호의식 배양', '자기 성찰 및 치유', '활기 찬 삶'으로 나타났다. 이곳은 과거 신라시대 도성의 중심 지역이었으며, 현재는 경주 역사유적 대 릉원 지구와 월성 지구 등이 위치한 넓은 평야지의 보존녹지지 역으로 역사·문화와 함께 녹지 및 휴게공간이 어우러진 공간 적 특성을 지니고 있다. 이러한 공원 녹지의 방문 및 이용 목적 에 대한 주요 선택 속성에 있어 '산책 및 휴식'임을 도출한 Park (2010), Kim et al.(2014)의 연구 결과와 일치한다. 각 단 계별 중요 항목의 인지는 고분을 활용한 공원의 관리와 조성에 대한 전략적인 방향성 제시에 중요한 의미를 가질 수 있다.

두 번째로, 지역주민과 관광객의 가치사슬 $(\mathrm{A}-\mathrm{C}-\mathrm{V})$ 에 밝혀 진 주요 내용을 살펴보면, 지역주민은 '휴식(휴양) 및 산책-스 트레스 해소-역사 · 문화 보호 의식 배양' 관광객은 '휴식(휴양) 및 산책-스트레스 해소-자기 성찰 및 치유'에 연결 관계가 강 하게 나타나고 있음을 알 수 있었다. 이는 지역주민과 관광객 에 모두 고분 방문에 가장 중요하게 고려하는 휴식(휴양) 및 산책은 스트레스 해소의 혜택을 가져다주는 중요 속성이며, 이 를 통해 최종 가치로 지역주민은 역사- 문화 보호 의식 배양, 관광객은 자기성찰 및 치유의 가치로 연결이 되고 있다는 것을 확인하였다. 먼저, 지역주민이 최종적으로 추구하는 역사· 문 화 보호 의식 배양의 가치 인식은 그들이 고분 방문의 휴식(휴 양) 및 산책을 통해 얻게 되는 스트레스의 해소로 나타나는 경 주 역사. 문화의 자긍심에 대한 긍정적인 영향을 미치는 것으 로 보이며, 관광객이 최종적으로 추구하는 자기성찰 및 치유의 가치인식은 이곳은 일정 사회 집단의 의례를 통해 일정 공간 범위 내에서 지속적으로 추가되어 구성되어진 죽음(death)의 공간적 특성과 함께 고분 주변으로 조성된 조경 공간의 휴식 (휴양) 및 산책을 통해 얻게 되는 스트레스의 해소로 나타나는 심리적인 현상으로 해석된다.

이와 같이 지역주민과 관광객 두 집단의 다소 다른 결과를 보인 가치사슬에 따라 '경주 도심 고분공원' 조성에 있어 그들
의 인지구조 차이에 대응한 공간계획의 차별화 전략으로 이어 져야 할 것이며, 또한 고분의 보존과 보호에 집중된 계획을 넘 어 양질의 역사·문화자원과 상호 연계한 조경계획을 통해 경 주만의 특성화된 지역전통 역사·문화공원의 발전과 이미지 강화가 요구되어진다. 이를 위해서는 문화유산 활용에 대한 제 도적 보완과 사회적 합의들의 대안이 우선적으로 이루어져야 할 것이다. 마지막으로 본 연구는 고분을 방문한 지역주민과 관 광객 336 명 대상의 조사로 정량적 조사방법 측면에서 이러한 표본수가 연구 결과의 일반화를 제한할 수 있으나, 래더링 방 법론은 연구의 일반화 목적이 아닌 다양한 시각을 통해 도출될 수 있는 변수 발견에 의의를 둔 것으로 이러한 연구의 시도에 큰 의미가 있다고 판단된다. 또한, 앞으로 문화유산 및 자연자 원을 활용한 공원조성계획에 있어 $\mathrm{MEC}$ 이론과 래더링의 심층 적인 방문 동기와 가치연구는 좀 더 효율적이며, 전략적인 공 간관리 및 활용방안계획에 유용한 정보로 활용할 수 있기를 기 대한다.

\section{References}

1. Cha, M. K. and S. H. Kweon(2013) A research on value chain structure generated from use of social media by performing arts consumers: Focusing on means-end chain theory. Journal of Cyber communication Academic Society 30(4): 219-261.

2. Choi. M. J.(2016) Yesterday and Today of the Preservation of Cultural Heritage in Korea. Seoul.

3. Cultural Heritage Administration(2007) Training on the Management and Repair of Cultural Assets, Historical Understanding: 109.

4. Cultural Heritage Administration(2009) A Study on the Improvement of Historic Site Designation System 2009.

5. Gutman, J.(1982) A means-end chain model based on consumer categorization processes. Journal of Marketing 46(2): 60-72.

6. Han, H. C., M. S. Cho, J. S. Oh and J. M. Seo(2011) Relationship between the HVM and cut-off level of means-end chain. The Korea Contents Society 11(4): 414-427.

7. Han, H J.(2007) A Study on bird Watcher's Value Using Means-End Chain Theory. Ph.D. Dissertation, Sejong University. Korea.

8. Hwang, B. C.(2008) A Study on the Pursuit Values of the Cultural Tour Visitors to Worldwide Heritages. Ph.D. Dissertation, Gyeong-gi University. Korea.

9. Jang, H. W.(2013) A Study on Cultural Tourist's Value Systems. Ph.D. Dissertation, Je-ju National University. Korea

10. Joo, J. S., C. S. Oh and Y. C. Kim(2006) Validity issues for qualitative researchers in educational/curriculum studies: Understanding different approaches. The Journal of Curriculum Studies 24(1): 61-95.

11. Kim, I. S. and M. H. Cho(2011) The analysis of the relationship among Jeju-Olle attributes, walking tourists' benefits and perceived values-application of means-end chain theory. The Journal of Tourism Studies 23(2): 127-154.

12. Kim, Y. S., H. Kim and J. S. Ko(2014) Analysis on the use characteristics of citizen based on urban green spaces type. Journal of the Korean Institute of Landscape Architecture 42(5):31-40.

13. Kwon, E. J., Y. H. Park and J. G. Park(2012) Understanding national park visitors' value system using laddering technique. The Tourism 
Sciences Society of Korea 36(5): 11-30.

14. Lee, J. K. and S. W. Ryu(2018) Analysis of audience's desire value for the Korean traditional performing art's using means-end chain theory. Korea Art Management Association. 46: 135-165.

15. Lee, J. W.(2018) A Study on the Theory and the Activation System for the Utilization of Cultural Heritage. Ph.D. Dissertation. Korea Traditional Culture University. Korea.

16. Lee, S. J.(2011) Preliminary study on defining and assessing heritage values for establishing conservation principles. National Research Institute of Cultural Heritage 44(4): 154-171.

17. Lee, S. J.(2017) The meaning, value and use of the Gaya ancient tombs. Keangnam Power Research Institute. 140: 8-27.

18. Lim, J. E. and H. R. Lee(2013) A study of urban park visitors' value pursuit using the laddering method. The Tourism Sciences Society of Korea 37(2): 11-29

19. Nunkoo, R. and H. Ramkissoon(2009) Applying the means-end chain theory and the laddering technique to the study of host attitudes to tourism. Journal of Sustainable Tourism 17(3): 337-355.

20. Olson, J. C. and T. J. Reynolds(1983) Understanding Consumer's Cognitive Structure Implications for Advertising Strategy, Advertising and Consumer Psychology, Lexington, MA: Lexington Books.

21. Park, C. I.(2010) A study on expansion of urban park and green belt basedon residents' attitude of park and green belt. The Journal of Korean institute of Forest Recreation 14(3): 29-37.

22. Song, G. I.(2012) The comparison of the hierarchical value map from smartphone user's involvement. Social Science Research Review 28(4): 303-328.

23. ter Hofstede, F., A. Audenaert, J.-B. E. Steenkamp and M. Wedel (1998) An investigation into the association pattern technique as a quantitative approach to measuring means-end chain. International Journal of Research in Marketing 15: 37-50.

24. Wassenberg, C. L., M. A. Goldenberg and K. E. Soule(2015) Benefits of botanical garden visitation: A means-end study, Urban Forestry \& Urban Greening 14(1) : 148-155.

Received : 23 January, 2019

Revised : 07 March, 2019

26 March, 2019

(1st)

(2nd)
3인익명 심사필 